\title{
Rm. 106
}

Geology of the

\section{Platteville Quadrangle}

Wisconsin

G EOLOG I C A L S URVEY B U L L E T I N 1123 - E

Prepared in cooperation with the

$W$ is consin Geological and

Natural History Survey

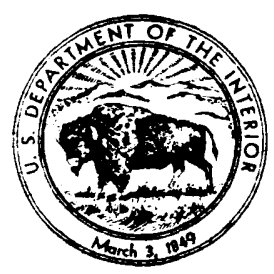

QE 75

B9

no.1123-E-I

- O.G.j.

( .6 
4

a

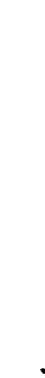

.

. 


\section{Geology of the}

\section{Platteville Quadrangle}

\section{Wisconsin}

By ALLEN F. AGNEW

GEOLOGY OF PARTS OF THE UPPER MISSISSIPPI VALLEY ZINC-LEAD DISTRICT

GE OL O G C A L S U R VEY B U L L E T I N $1123-\mathrm{E}$

Prepared in cooperation with the $W$ isconsin Geological and Natural History Survey

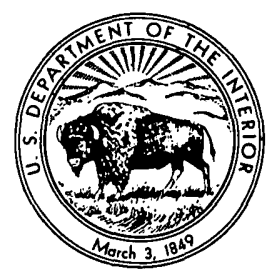




\section{UNITED STATES DEPARTMENT OF THE INTERIO" \\ STEWART L. UDALL, Secretary}

\section{GEOLOGICAL SURVEY}

Thomas B. Nolan, Director

For sale by the Superintendent of Documents, U.S. Government Printing Office Washington, D.C. 20402 


\section{CONTENTS}

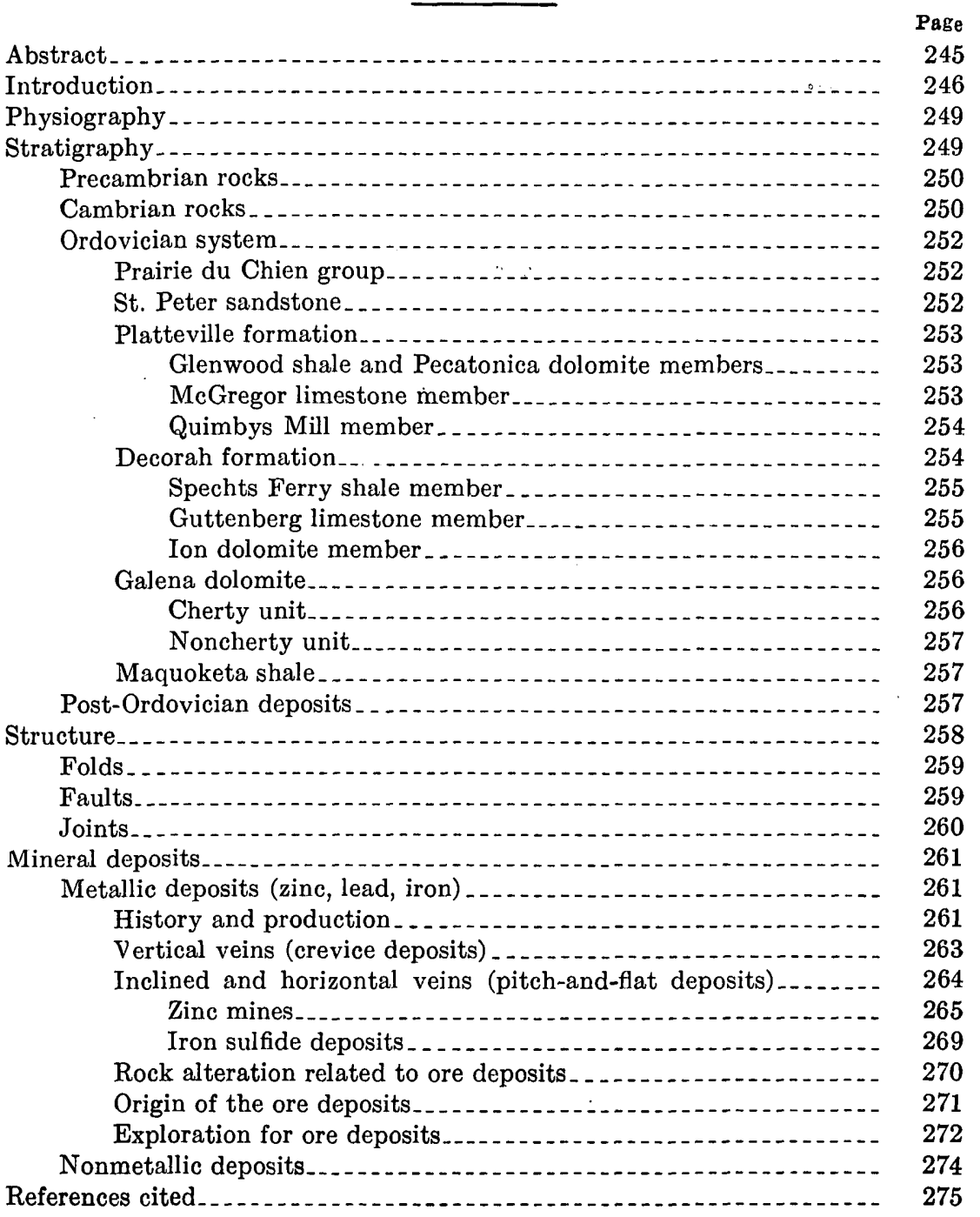




\section{ILLUSTRATIONS}

Page

Plate 19. Geologic map of the Platteville quadrangle.............. In pocket

FIGURE 38. Index map of the Wisconsin-Illinois-Iowa zinc-lead district.- 247

39. Areas of the Platteville quadrangle mapped in previous

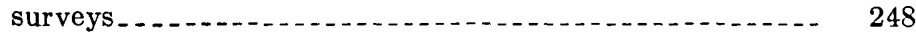

40. Generalized stratigraphic columnar section of rocks exposed in the Platteville quadrangle...................... 251

41. Total joints, crevices, and shears in the Platteville quadrangle . . . . . . . 260

42. Plat showing location of vertical-vein (crevice) lead deposits mapped in the Platteville quadrangle ...............

\section{TABLE}

TABLE 1. Location of zinc mines in the Platteville quadrangle......... 


\title{
GEOLOGY OF PARTS OF THE UPPER MISSISSIPPI VALLEY ZINC-LEAD DISTRICT
}

\section{GEOLOGY OF THE PLATTEVILLE QUADRANGLE, WISCONSIN}

\author{
By Allen F. Agnew
}

\begin{abstract}
The Platteville quadrangle is in southwest Wisconsin, in the WisconsinIllinois-Iowa zinc-lead district. Sedimentary rocks exposed in the quadrangle are, in ascending order: the upper members of the Platteville formation, the Decorah formation, and the Galena dolomite, all of Middle Ordovician age, and the Maquoketa shale of Late Ordovician age. Rocks penetrated by drill holes and wells but not exposed are, in ascending order: Precambrian granitic rocks; sandstone, siltstone, and dolomite of Late Cambrian age; the Prairie du Chien group of Early Ordovician age; the St. Peter sandstone of Middle Ordovician age; and the lower members of the Platteville formation. Loess of Quaternary age and a residual mantle of soil cover the bedrock.

The rocks have a slight regional dip southwestward and are warped by gentle folds that strike northeastward or northwestward and average about 30 feet in amplitude. Locally, the amplitudes of small folds may be increased or decreased through leaching of carbonate rocks by mineralizing solutions. Part of the north limb of the Meekers Grove anticline, a fold having about 140 feet of structural relief, underlies the southeastern part of the quadrangle. Joints and small faults parallel the small folds or diverge from their trends at a small angle; joints that are most open strike eastward.

Metallic mineral deposits include zinc, lead, and iron minerals. Vertical veins (crevice deposits) contain principally galena; some contain smithsonite near the water table and sphalerite below it. Most of the lead ore produced was from the second and upper flint openings in the Galena dolomite, along solution-widened vertical or steeply inclined fractures. Concentrations of galena occur in residual clay above or near crevice deposits.

Zinc ore occurs in inclined and horizontal veins (pitch-and-flat deposits) and in related solution breccia and disseminated deposits. These are found in the lower part of the Galena dolomite, in the Decorah formation, and in the Quimbys Mill member of the Platteville formation; the fractures that control them are related to folding. Sphalerite is accompanied by a gangue of pyrite, marcasite, calcite, and barite; oxidation has produced secondary carbonates, oxides, and sulfates. The iron sulfides are a potential source of sulfur. Alteration of the host rocks by leaching, thinning, dolomitization, and some silicification is related to mineralization.

Nonmetallic mineral deposits include barite that occurs with the metallic minerals, building stone, clays, cement materials, road aggregate, agricultural limestone, and soils.
\end{abstract}




\section{INTRODUCTION}

The Platteville quadrangle, part of the Wisconsin-Illinois-Iowa zinc-lead district, contains about 54 square miles in eastern Grant and western Lafayette Counties, Wis. (fig. 38). It lies wholly within the Driftless Area (Whitney, 1862, p. 117-120; Shaw and Trowbridge, 1916, fig. 3). The principal city, Platteville, is in the northwest corner of the quadrangle.

Important contributions to the geology of the Upper Mississippi Valley mining district and thus to the geology of the Platteville quadrangle were made by Owen (1840), Daniels (1854), Percival (1855, 1856), Whitney (1862), Strong (1877), Chamberlin (1882), Grant (1903), and Bain (1906). Parts of the quadrangle were mapped (fig. 39) by Grant (1906, pls. 10, 16), Grant and Burchard (1907), Steidtmann (1909, pls. 1-3), and Heyl and others (1945).

The geology of the Platteville quadrangle (pl. 19) was mapped in cooperation with the Wisconsin Geological and Natural History Survey as part of a geologic study of the zinc-lead district (Heyl and others, 1959). The study includes surface geologic mapping and detailed investigation of mines. Detailed geologic studies of small areas of extensive mining and exploration made between 1942 and 1951, together with the present mapping program, indicate potentialities for future exploration for zinc-lead ore deposits.

Field mapping of the Platteville quadrangle began in July 1952 and ended in November 1953. A compilation of field data from aerial photos was made on a base map at a scale of 1:7,920. The additional information and new interpretations have revised geologic boundaries and structure shown on older maps of the area. The structure contours shown on plate 19 are based on detailed stratigraphic studies of outcrops and on examination of cuttings from prospect holes and water wells drilled by individuals and mining companies, and from holes drilled by the U.S. Geological Survey (Agnew, 1953). Altitudes of exposed rocks and of many drill-hole collars were surveyed by planetable and alidade and this information was reduced to a common datum surface, the top of the Platteville formation. In certain areas, as secs. 13 and 24, T. 3 N., R. 1 W., the structure contours are based mainly on the Steidtmann (1909) survey because these areas do not contain useful outcrops or recent drill holes.

The author gratefully acknowledges the cooperation of W. N. Smith and O. E. DeWitt of the Vinegar Hill Zinc Co.; J. M. Hague and R. B. Paul of the New Jersey Zinc Co.; C. T. Millice of the American Zinc, Lead, and Smelting Co.; and C. W. Stoops, an independent mine operator in Platteville. These men and the companies they represent aided the study of the Platteville quadrangle by furnishing 

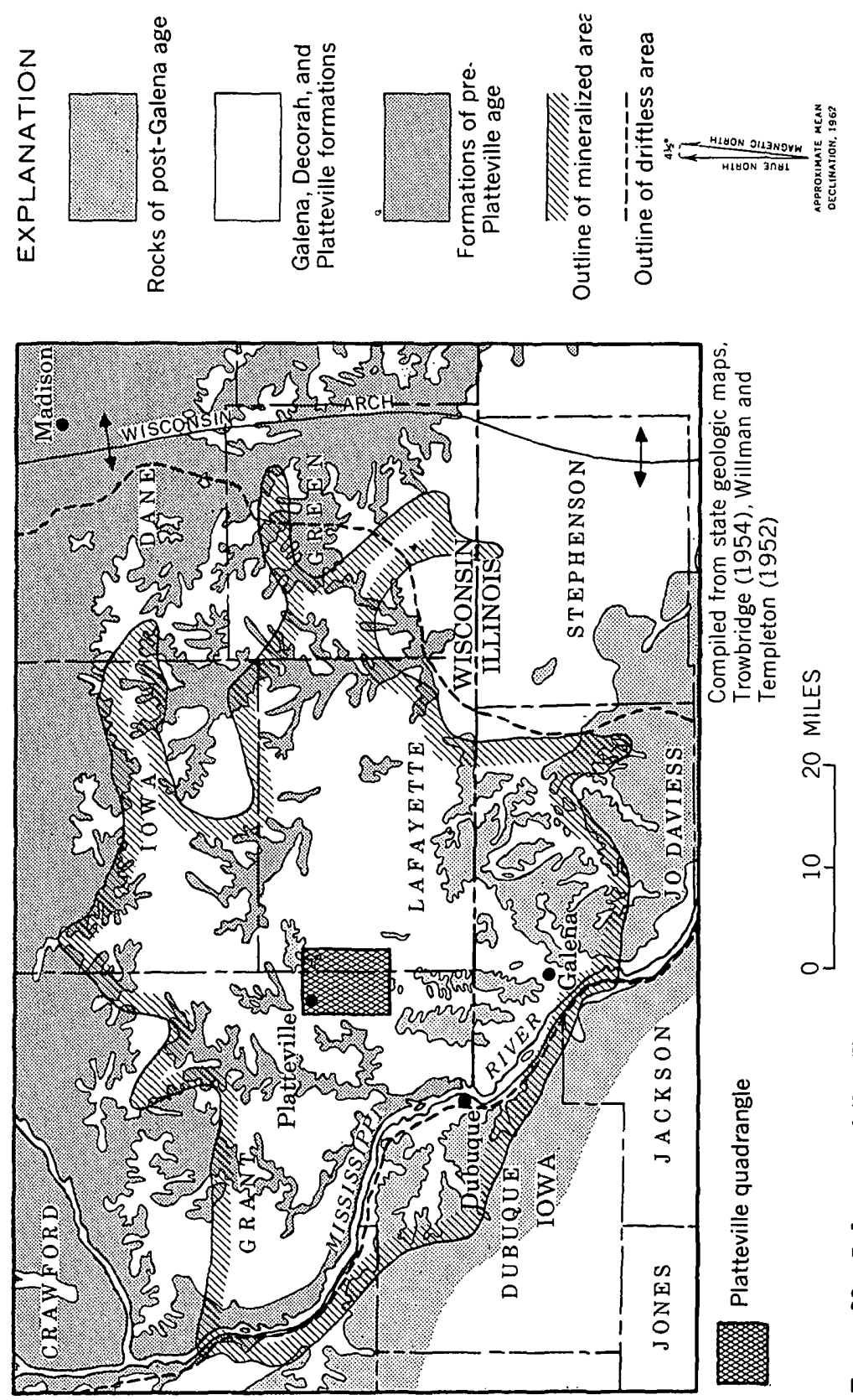

焉焉 
drill-hole and mine data. The writer is indebted to his colleagues of the U.S. Geological Survey for their assistance, suggestions, and critical comments in the preparation of this report, especially to Thomas E. Mullens.

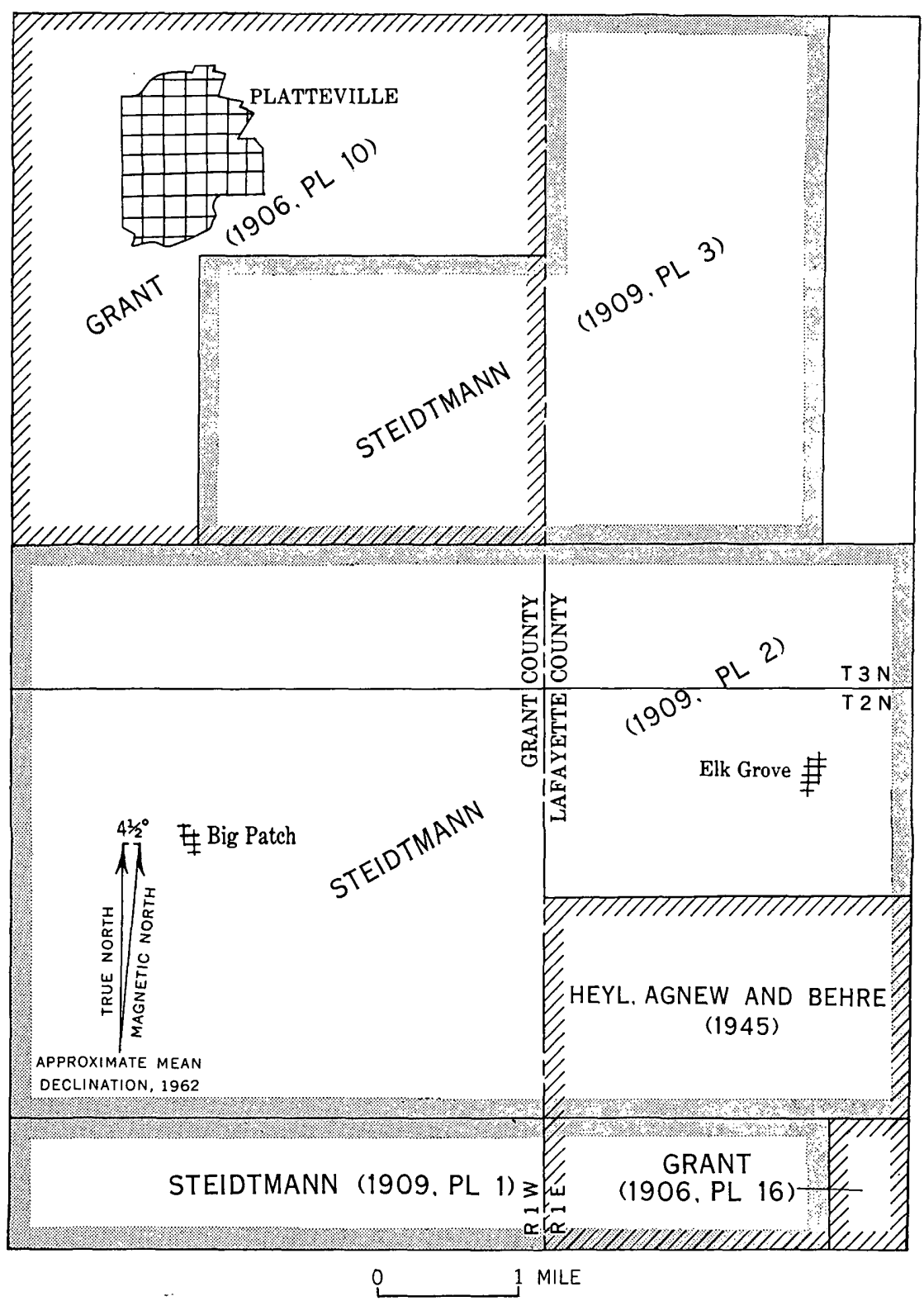

Figdre 39.-Areas of the Platteville quadrangle mapped in previous surveys. 


\section{PHYSIOGRAPHY}

The topography of the Driftless Area, which differs markedly from that of the surrounding glaciated region, was described by Irving (1877, p. 610-611) and by Chamberlin and Salisbury (1885) ; Owen (1840) had earlier noted the absence of drift in the mining district.

The topographic surface of the Platteville quadrangle is in the erosional stage of early maturity. The maximum altitude is 1,170 feet, in the northeastern corner of the quadrangle, and the minimum is 790 feet, in the southwestern part, but local topographic relief does not exceed 165 feet. The valleys are generally broad with gentle slopes and flat bottomlands. The eastern part of the quadrangle is drained by the southward-flowing Galena (Fever) River, and the western part is drained by several westward-flowing tributaries of the Little Platte River. Both rivers are tributary to the Mississippi.

The summits of the interfluvial areas of the quadrangle appear to be accordant, and the upland surface slopes southward. The amplitudes of minor folds are too small to disclose accurately any possible beveling of structure by the upland surface; however, the major Meekers Grove anticline, along the south edge of the Platteville quadrangle, is beveled by the general southward topographic slope. This surface may represent a partly dissected peneplain (Martin, 1916, p. 55-70) ; Trowbridge, 1921); but because of the general similarity of its slope (17 feet per mile) to the regional dip (16 feet per mile) as reported by Agnew $(1955$, p. 784$)$, the surface is herein interpreted as structural.

Uplands are mainly farmland and grassland. Most stream valleys are covered with grassland, although some are bordered by small woodlots.

\section{STRATIGRAPHY}

Bedrock units exposed in the Platteville quadrangle are, in ascending order : the McGregor and Quimbys Mill members of the Platteville formation, the Decorah formation, and the Galena dolomite, all of Middle Ordovician age, and the Maquoketa shale of Late Ordovician age. Also exposed are loess of Quaternary age, chert gravel of undetermined age, and quartz sandstone that fills joints in the Galena dolomite and is of undetermined age.

Pre-Platteville rocks, although not exposed in the quadrangle, have been penetrated by drill holes and are also known from exposures nearby. They lie on a Precambrian granitic basement and include, in ascending order: the Dresbach group, Franconia sandstone, and Trempealeau formation, all of Late Cambrian age; the Prairie du

$663375-62-2$ 
Chien group of Early Ordovician age; the St. Peter sandstone of Middle Ordovician age; and the Glenwood shale and Pecatonica dolomite members of the Platteville formation, also of Middle Ordovician age.

The general nature of the stratigraphic units is presented in the paragraphs that follow. For detailed lithology of the exposed rocks see figure 40, and for regional relations of these rocks see Agnew and others (1956).

\section{PRECAMBRIAN ROCKS}

An igneous and metamorphic complex of granite, gneiss, schist, and quartzite forms the pre-Paleozoic basement in southwestern Wisconsin (Thwaites, 1931). Within the Platteville quadrangle Precambrian "granite" was reported at the depth of 1,714 feet in Platteville city well $2(\mathrm{NW} 1 / 4 \mathrm{SE} 1 / 4$ sec. 14, T. 3 N., R. 1 W.). Precambrian rocks have been penetrated by deep wells elsewhere in the mining district (Anderson, 1950).

\section{CAMBRIAN ROCKS}

Information concerning Cambrian strata was obtained by examination of drill cuttings from city wells 2 and 3 at Platteville, and from No. 2 at Cuba City, which is $1 \frac{1}{2}$ miles south of the Platteville quadrangle. The principal data are tabulated below.

Generalized description of Cambrian rocks underlying the Platteville quadrangle, Wisconsin

\begin{tabular}{|c|c|c|c|}
\hline \multicolumn{2}{|r|}{ Formation } & Lithology & Thickness \\
\hline \multicolumn{2}{|c|}{ Trempealeau } & Sandstone, dolomite, dolomitic siltstone...- & $142-155$ \\
\hline & $\begin{array}{l}\text { Franconia } \\
\text { sandstone }\end{array}$ & $\begin{array}{l}\text { Sandstone, locally dolomitic siltstone, and } \\
\text { sandy shale; glauconitic. }\end{array}$ & $91-115$ \\
\hline 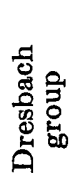 & $\begin{array}{l}\text { Galesville } \\
\text { sandstone } \\
\text { Eau Claire } \\
\text { sandstone } \\
\text { Mount Simon } \\
\text { sandstone }\end{array}$ & Salomitic sandstone, shale & $\begin{array}{c}135-162 \\
111-355 \\
778\end{array}$ \\
\hline
\end{tabular}




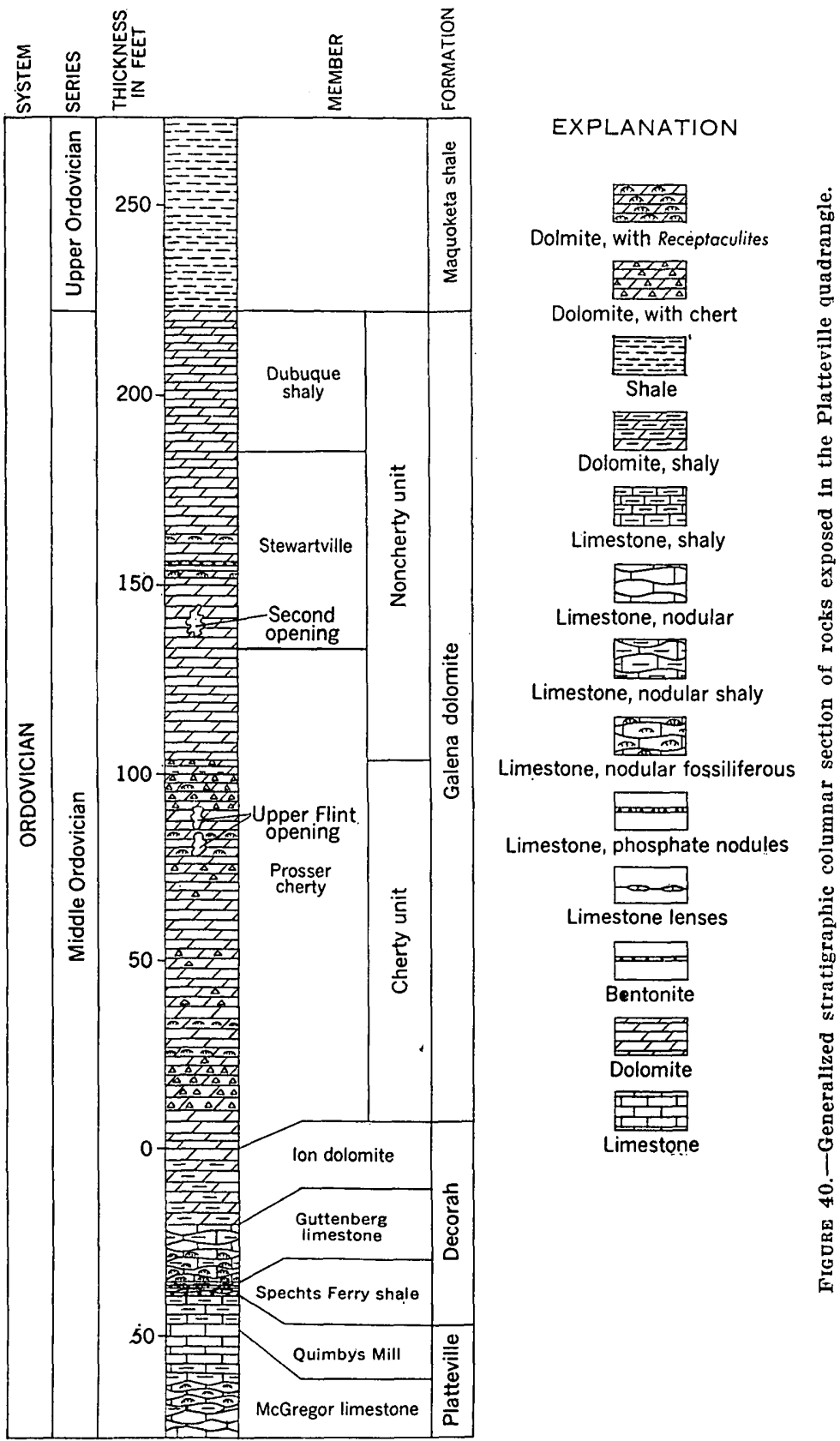




\section{ORDOVICIAN SYSTEM}

\section{PRAIRIE DU CHIEN GROUP}

The Prairie du Chien group of Early Ordovician age is not exposed in the Platteville quadrangle but it was penetrated by the Platteville city wells and by eight other wells not more than $21 / 4$ miles from the quadrangle. Upper beds of the Prairie du Chien crop out along the Pecatonica River about 10 miles northeast of Platteville and along the Little Platte River about 3 miles north of Platteville. The complete section of the Prairie du Chien is exposed about 30 miles north of Platteville in the bluffs along the Wisconsin River; there it conformably overlies the Trempealeau formation.

Well cuttings from four of the localities including Platteville showed a typical sequence of brown to yellowish-gray fine-grained dolomite locally contained nodules or irregular masses of gray chert. This typical Prairie du Chien is 207 to 225 feet thick near Platteville and 255 to 267 feet near Cuba City. The other well cuttings show an anomalous combination of red and green shale, sandstone, chert, silicified limestone, and limestone at the stratigraphic position of the Prairie du Chien group. These strata have been considered a part of the Prairie du Chien (Flint, 1956) or the basal part of the overlying St. Peter sandstone (Heyl and others, 1951, p. 15).

In two wells near Cuba City, pyrite and marcasite were in cuttings from the lower 47 to 85 feet of normal dolomite of the Prairie du Chien. This, and evidence in other parts of the mining district, shows that dolomite in the Prairie du Chien is a potentially favorable host rock for iron, zinc, and lead sulfide deposits (Heyl and others, 1951; Agnew and others, 1953, p. 7-11).

\section{ST. PETER SANDSTONE}

The St. Peter sandstone of Middle Ordovician age is not exposed in the Platteville quadrangle, but it crops out in stream valleys less than 1 mile from the southeastern and northwestern corners of the quadrangle. Additional information regarding the St. Peter was obtained from the records of the wells mentioned in the discussion of the Prairie du Chien group.

The St. Peter is a very clean quartz sandstone that is generally well sorted and averages 50 feet in thickness. Where rock that resembles St. Peter sandstone occupies part of the Prairie du Chien interval, as at the well localities cited above, the thickness of the St. Peter sandstone, or at least of sandstone like the St. Peter, ranges from 138 to 320 feet. In some places the upper 40 to 60 feet of this sandstone is better sorted than the rest; in other places there appears 
to be no difference in lithology throughout the sequence. For this reason the St. Peter and Prairie du Chien thicknesses are commonly combined. In the Platteville quadrangle they total 270 to 340 feet.

The St. Peter sandstone is normally not mineralized with zinc and lead; however, outside the Platteville quadrangle small amounts of zinc and lead sulfides have been found where fractures connect the St. Peter with mineralized parts of higher beds (Percival, 1855, p. 55 ; Whitney, 1862, p. 363). A zone of pyrite-cemented quartz grains about 5 feet below the top of the St. Peter sandstone weathers to a yellowish-brown resistant ledge and forms a good stratigraphic marker. In unoxidized drill cuttings the glittering fragments from this zone are very distinctive.

\section{PLATTEVILLE FORMATION}

The Platteville formation of Middle Ordovician age consists of four members which, in ascending order, are: the Glenwood shale, the Pecatonica dolomite, the McGregor limestone, and the Quimbys Mill. Only the McGregor and Quimbys Mill members are exposed in the Platteville quadrangle. The complete thickness of the Platteville formation, however, has been penetrated in several wells in the quadrangle, and information from these wells is supplemented by exposures and records of wells drilled near the borders of the quadrangle. The Platteville formation rests with apparent conformity on the St. Peter sandstone and ranges from 55 to $671 / 2$ feet in thickness in and near the Platteville quadrangle.

\section{GLENWOOD SHALE AND PECATONICA DOLOMITE MEMBERB}

The Glenwood shale and Pecatonica dolomite members are not exposed in the Platteville quadrangle. The green sandy shale of the Glenwood and the grayish-brown sugary dolomite of the Pecatonica are not favorable host rocks for ore minerals, although locally small amounts of zinc and lead minerals have been found (Agnew and others, 1956). Therefore, a detailed description is not attempted here.

\section{MOGREGOR LIMESTONE MEMBER}

The McGregor limestone member of the Platteville formation is exposed in the northwestern part of the quadrangle in bluffs along the Little Platte River. These outcrops and others just beyond the quadrangle borders exhibit two units of contrasting lithology. The lower unit consists of thin nodular beds of dense dolomitic limestone containing partings of grayish shale; gastropods are common. The upper unit of the McGregor is less dense, thicker bedded, and less fossiliferous than the lower. These two lithologic units of the McGregor 
are regarded as facies. The thicknesses of the units tend to complement each other, and a total thickness of 29 to 31 feet for the McGregor is relatively constant although in different localities the upper part of the member may range from 11 to 18 feet in thickness (Agnew and others, 1956).

A transitional bed 1 foot thick of light-gray sublithographic limestone marks the top of the McGregor member. Except for its color, this dense vitreous mottled limestone resembles limestone of the over. lying Quimbys Mill member.

In the mining district the McGregor strata are regarded as poten. tial host rocks for ore. Many prospect holes in the east half of tho Platteville quadrangle have penetrated deposits of combined zinc, lead, and iron sulfides, but none of the deposits discovered to date is of current economic value.

QUTMBYS MILI MEMBER

The Quimbys Mill member is exposed in the northwestern part of the Platteville quadrangle along the Little Platte River, where it caps bluffs of the McGregor member, and along Rountree Branch. In these and nearby exposures the Quimbys Mill is a purplish-gray finegrained dense medium-bedded limestone marked by a dark-brown shale bed 0.1 foot thick at its base and a fucoidal limestone bed 0.4 foot thick at its top. Because the limestone is dense and breaks with a conchoidal fracture, it is locally called glass rock. The Quimbys Mill is 3 feet thick along the western edge of the Platteville quadrangle and thickens to 10 feet along the eastern border.

The upper surface of the Quimbys Mill member is pitted, has a reddish crust, and appears to have been locally eroded (Chamberlin, 1882, p. 413). Erosion is confirmed by the regionally disconformable relations between the Quimbys Mill and the overlying Decorah formation (Agnew and Heyl, 1946; Agnew and others, 1956). The brown shale at the base of the Quimbys Mill rests conformably on the McGregor limestone member.

In the east half of the Platteville quadrangle many prospect holes in the Quimbys Mill member have penetrated zinc, lead, and iron sulfides, which are locally of ore grade. The Quimbys Mill member was quarried along the Little Platte River just west of Platteville, and the glass-rock stone is preserved in many of the older buildings in the city of Platteville.

\section{DECORAF FORMATION}

The Decorah formation is of Middle Ordovician age. Its three members-in ascending order, the Spechts Ferry shale, the Guttenberg limestone, and the Ion dolomite-are exposed in the northwestern part 
of the Platteville quadrangle along the Little Platte River. The upper two members crop out along Rountree Branch, a tributary of the Little Platte; the upper member only is exposed along Blockhouse Creek, at the midpoint of the western border of the quadrangle, and along Pats Creek and the Galena (Fever) River in the southeastern part of the quadrangle. Most of the prospect holes and many of the wells in the mapped area penetrate Decorah strata. The Decorah is normally 37 to 40 feet thick in the Platteville quadrangle. It rests disconformably on the Platteville formation and is conformable with the overlying Galena dolomite (Agnew and others, 1956). In the quadrangle, as in the rest of the mining district, the upper two members of the Decorah are locally ore bearing.

\section{BPECHTS FERRY BHALE MEMBER}

The Spechts Ferry shale member is well exposed only where limestone ledges of the units above and below crop out. Most commonly the Spechts Ferry is partly or completely covered, but its position may be marked by springs or seeps. The Spechts Ferry is mainly green shale and greenish-buff argillaceous limestone. A bentonite layer near the base and phosphatic nodules near the top are particularly distinguishing features of the unit. Along the western border of the quadrangle the Spechts Ferry is 6 feet thick and is about one-third limestone. At the eastern border it is only 3 feet thick and is threefourths limestone, so the thinning apparently reflects a decrease in the amount of shale.

Disseminated zinc, lead, and iron sulfides are present in the Spechts Ferry shale member, but because of the lithology and the disseminated nature of the minerals the Spechts Ferry is normally not considered a potential host rock for ore deposits.

The Spechts Ferry is overlain conformably by the Guttenberg limestone member.

\section{GUTTENBERG LIMESTONE MEMBER}

The Guttenberg limestone member is exposed as ledges along stream valleys above the reentrant formed by the Spechts Ferry shale. The Guttenberg is mainly light-brown fossiliferous fine-grained dense nodular limestone that contains partings of brown platy shale. Near the top it contains a discontinuous band of cream-colored chert nodules. The member is 14 to 16 feet thick.

The Guttenberg member, known locally as the oil rock because of its content of bituminous material (Bain, 1906, p. 25-27), is an orebearing unit that marks the base of many inclined-vein (pitch-andflat) deposits of zinc and lead minerals. In addition, the Guttenberg contains a few deposits of disseminated sphalerite and galena; this type 
of deposit has been mined west of Platteville in the Hill or West Hill mine (NW1/4 sec. 16, T. 3 N., R. 1 W.).

\section{ION DOLOMITE MEMBER}

Like the Guttenberg member, the Ion dolomite member is exposed as ledges along stream valleys. The Ion is normally gray mediumgrained crystalline dolomite intercalated with olive-gray dolomitic shale partings; in places it is limestone. The lower 6 to 8 feet of the Ion, locally called the blue beds, is commonly darker, more granular, more shaly, and more fossiliferous than the upper part, which is called the gray beds. The Ion is 19 to 20 feet thick.

The Ion member is one of the major ore zones in the Platteville quadrangle; it constitutes the lower part of most of the inclinedvein (pitch-and-flat) deposits and was the principal rock mined in the Blockhouse mines (west-central part of quadrangle) and other mines.

\section{GALENA DOLOMITE}

The Galena dolomite of Middle Ordovician age is the bedrock in most of the Platteville quadrangle. It crops out as ledges in stream bottoms and along bluffs and valley slopes. The Galena dolomite has been subdivided mainly on paleontologic criteria into three membersin ascending order, the Prosser cherty member, Stewartville member, and Dubuque shaly member. These members are not consistently recognizable in the mining district, so for mapping purposes the Galena is subdivided on lithologic criteria into the cherty unit below and the noncherty unit above (Agnew and others, 1956).

\section{CHERTY UNIT}

The lower or cherty unit of the Galena dolomite is normally 101 to 107 feet thick. It consists mostly of buff coarse-grained compact to granular thin-bedded to massive dolomite, but locally light-buff finegrained dense limestone occurs in the lower 20 to 25 feet. The rela. tive abundance of chert, the presence of the fossil Receptaculites, and differences in bedding and weathering characteristics are used for division of this unit into four zones: the lower buff, the lower chert, the lower Receptaculites, and the upper chert zones.

The cherty unit of the Galena rests conformably on the Decorah formation; the basal few feet of the Galena contains shaly or silty partings with olive-green argillaceous patches (brown in mineralized areas) and is transitional with the Ion member below, irrespective of whether the strata are mostly dolomite or limestone.

The upper parts of many inclined-vein deposits of zinc-lead ore are in the lower three zones of the cherty unit, and vertical-vein lead deposits are in the upper 30 feet of the upper zone. 


\section{NONCHERTY UNIT}

The noncherty unit of the Galena dolomite covers most of the upland of the Platteville quadrangle; it is 115 to 120 feet thick. It is more yellowish in its lower part than the cherty unit, and is thinbedded and shaly in its upper part. The lower part of the noncherty unit contains lead deposits of the vertical-vein type like those in the underlying cherty unit.

\section{MAQUOKETA SHALE}

The Maquoketa shale of Late Ordovician age is mapped in the Platteville quadrangle as covering some of the uplands in the northeastern and southwestern parts where the land surface rises above the top of the Galena formation. The maximum thickness of Maquoketa shown by the map is about 50 feet; however, a cap of loess is present on the uplands. This loess cap may total 20 feet thick or more; thus in much of the area where Maquoketa is mapped as bedrock, the Galena dolomite may actually be overlain by loess or by only a few feet of Maquoketa shale, and that in turn by loess. Drill holes and exposures just north and east of the quadrangle show interbedded grayish-blue fissile shale and fossiliferous argillaceous granular dolomite in the basal 20 feet of the Maquoketa shale. The lower few feet contains a zone of small fossils. This is the depauperate zone described by Ladd (1929, p. 371-375) as a zone of universal smallness. The term "depauperate". as used in this report refers to the small size of the individual fossils and is being used as a stratigraphic term without genetic implications.

The base of the Maquoketa shale is marked by springs, which can be used, with discretionary limits, for mapping geologic structure.

The Maquoketa contains iron minerals in its basal or depauperate zone; the formation is not considered a favorable host rock for zinc or lead ore deposits (for another view, see Cox, 1911, p. 587-588).

\section{POST-ORDOVICIAN DEPOSITS}

Within the Platteville quadrangle, deposits of post-Maquoketa age include loess, chert gravels, valley fill and terrace alluvial deposits of clay, sand, and gravel; and quartz sandstone in joints in the Galena dolomite. The loess is Pleistocene in age and is generally thickest, locally more than 20 feet, on the uplands. It was deposited on a residual soil which is also thickest on the uplands.

The chert gravels are at the heads of the gullies and ravines in the northeastern part of the quadrangle, and they are derived from chertbearing Silurian rocks. These chert gravels are possibly comparable in age, relative position, and lack of glacial material to the Tertiary (?) 
gravels (Trowbridge, 1954, p. 799-800) farther south along the Mississippi Valley.

Boulders of quartz sandstone in joints about 30 feet below the top of the cherty unit of the Galena dolomite are exposed in a lead-mine shaft in the northern part of the city of Platteville (just south of the center of sec. 10, T. 3 N., R. 1 W.). Boulders of quartz sandstone also occur about 40 feet below the top of the cherty unit of the Galena near the top of a bluff about 1.5 miles west of the border of the quadrangle (SE $1 / 4$ NE $1 / 4$ sec: 19, T. 3 N., R. 1 W.). In the shaft of a lead mine 1 mile south of the second locality, sandstone at about the same stratigraphic position was traced to a depth of 80 feet. The sandstone and boulders contain fragments of angular white or cream chert like that in the cherty unit of the Galena but are otherwise like the St. Peter sandstone, 150 feet stratigraphically below. The anomalous materials appear to have been deposited in open joints by a post-Galena, possibly Pennsylvanian, sea, but other somewhat similar occurrences in the mining district seem to be more reasonably explained as dikelike intrusions from below, or by ice-rafting.

\section{STRUCTURE}

The mining district lies on the western limb of the Wisconsin arch and is south-southwest of a structural high of Precambrian rocks in central Wisconsin. The regional dip in the district is about 16 feet per mile south-southwest, and within the Platteville quadrangle it is 12 to 15 feet per mile. The rocks of the mining district are fractured and gently folded into generally broad shallow synclines and anticlines that average half a mile across and about 30 feet in structural relief. The Meekers Grove anticline, whose axis is a short distance beyond the southeast corner of the Platteville quadrangle, is a more pronounced fold.

The significant structures that control the position of the ore deposits are folds of small amplitude-10 to 30 feet-and fractures of very small displacement-measurable in inches to a few feet. These folds and fractures were locally modified by variations in lithology, by irregularities in underlying rocks, and by rock alteration.

Although the regional structures and many of the small folds and fractures are due to tectonic deformation, a few local structures may be partly a reflection of leaching, compaction, folding, and fracturing which were caused by earlier depositional features such as reeflike domes in the Prairie du Chien group, or by slumping along vertical joints because of selective leaching of more soluble zones in the Galena, Decorah, and Platteville formations. 
In the mapping of this quadrangle, distinctive stratigraphic zones, marker horizons, and lithologic features were used for correlations and in the plotting of structure contours shown on plate 19. There are fewer distinctive features above the lower chert zone of the cherty unit of the Galena dolomite than below it; therefore, extrapolation downward from exposures in the middle and upper beds of the Galena dolomite to the Platteville-Decorah contact, which was used as a datum surface, is likely to result in a less accurate interpretation of structure than extrapolation upward from lower horizons. Furthermore, because of thinning in the Guttenberg and Quimbys Mill members, tectonic structure mapped above these members may not be as accurate in detail as structure mapped below them. Nevertheless, the significant structural features are apparent on plate 19. The Platteville-Decorah contact was used as the datum because it is easiest to recognize in exposures and drill cuttings.

The contrast between the simple structure shown in the northeastern part of the quadrangle and the complex structure shown elsewhere on plate 19 is partly a result of difference in the amount of geologic information available.

\section{FOLDS}

The crest of the Meekers Grove anticline trends northeastward at the extreme southeast corner of the Platteville quadrangle. The fold is asymmetric and is locally modified by bifurcations of its general trend and by northwestward-trending cross folds. Its structural relief is as great as 140 feet in 1,500 feet. Just east of the quadrangle this anticline is faulted along its northern flank, and it interrupts northwestward-trending cross folds (Heyl and others, 1959, pl. 3). As a primary structure it may be related to faulting at depth.

The many smaller folds are generally closely spaced, and are elliptical. These folds trend N. $40^{\circ}$ to $60^{\circ} \mathrm{E}$. in the southeastern part of the quadrangle and N. $60^{\circ}$ to $75^{\circ} \mathrm{E}$. in the central and northwestern parts. Another group of small crossfolds trends generally N. $35^{\circ} \mathrm{W}$., and the two systems make a general rhombic pattern. Locally, as suggested by much information in the southeastern part of the quadrangle, the amplitude of the folds may have been increased or diminished by leaching in the Decorah and Platteville formations.

\section{FAULTS}

Major faults in the mining district are rare. One vertical fault with a horizontal displacement of about 30 feet was mapped just east of the Platteville quadrangle (Heyl and Agnew, 194.5), 1,000 feet east of the Lawrence mine (NW1/4 sec. 16, T. 2 N., R. 1 E.). Structures that may be faults in Platteville (NW. corner sec. 15, 
T. 3 N., R. 1 W.) and $11 / 2$ miles to the southeast (NW1/4 sec. $23, \mathrm{~T}$. 3 N., R. 1 W.) have been mapped as sharp folds. Both structures are based on inconclusive descriptions of drill-hole records by Grant $(1903,1906)$ and Steidtmann (1909). Other irregularities in structure contours are interpreted as the result of leaching effects superimposed on tectonic structural features.

Minor faults associated with mineral deposits are described in the section "Mineral deposits."

\section{JOINTS}

Three general directions of joints are most common in the rocks of the Platteville quadrangle (fig. 41 ) : N. $55^{\circ}$ to $90^{\circ}$ W., N. $10^{\circ}$ to $35^{\circ} \mathrm{E}$., and $\mathrm{N} .60^{\circ}$ to $70^{\circ} \mathrm{E}$. Other, less abundant joint directions are shown in figure 41 . In general the joints appear to diverge from the trends of the folds at a small angle, although in places they parallel the fold axes. Most of the joints that strike nearly due east have been enlarged by solution of the calcareous rocks and are more open than the other joints. These mineralized fractures are notably consistent in strike.

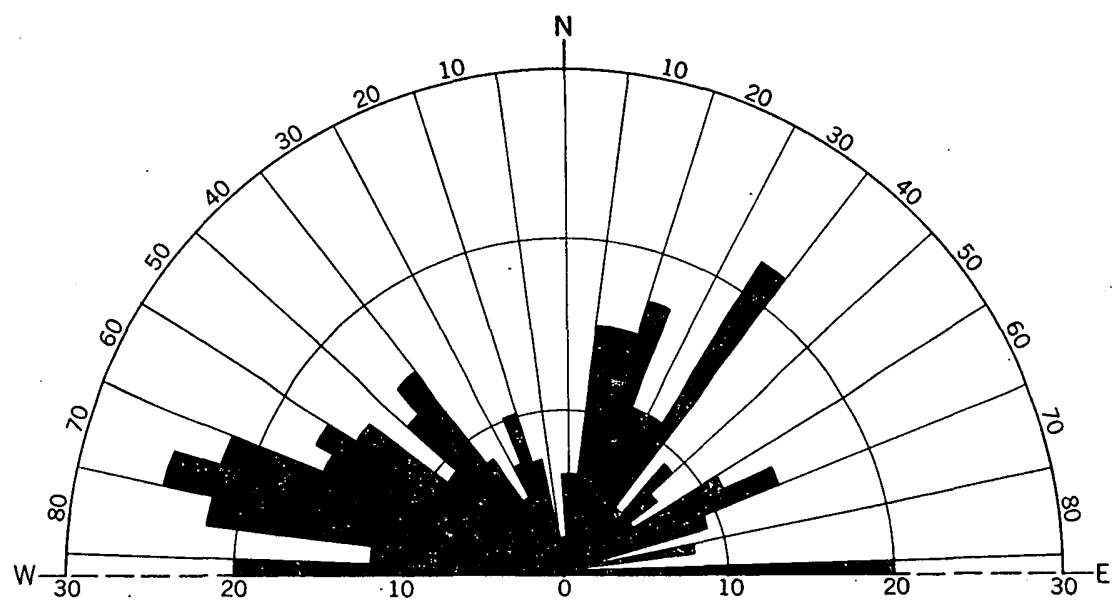

Figure 41.-Total joints, crevices, and shears in the Platteville quadrangle. Compilatiou of 400 joints; each concentric interval represents 10 joints.

In mineralized areas, groups of closely spaced inclined or vertical fractures formed by shearing are common; they are marked by altered rock, oxidized iron minerals, or springs. In places the courses of the Galena (Fever) and Little Platte Rivers and many of the smaller streams are controlled by joints and zones of shearing (Agnew and others, 1954). 


\section{MINERAL DEPOSITS}

\section{METALLIC DEPOSITS (ZINC, LEAD, IRON)}

\section{HISTORY AND PRODUCTION}

The Wisconsin-Illinois-Iowa zinc-lead district, of which the Platteville quadrangle is a part, has been productive for more than 125 years. Groups of shallow pits and shafts, locally known as diggings, are evidence of early mining and exploration mainly for lead minerals (Owen, 1840; Percival, 1855, 1856; Whitney, 1862; Strong, 1877). Indian diggings were known to traders before white miners settled in the district in about 1820 .

Records indicate that a man named Metcalf, who discovered galena in 1827 near the Rountree range in the city of Platteville (SE1/4 sec. 15, T. 3 N., R. 1 W.), was the first white miner in the Platteville quadrangle. Between 1827 and 1843 about 14,800 tons of lead concentrate was produced in the Platteville area (Heyl and others, 1959, p. 242). The ore came mainly from groups of shallow pits and shafts in areas shown in figure 42. In 1839 the three furnaces shown in figure 42 produced 1,250 tons of lead (Owen, 1840, p. 34-35), but 20 to 30 years later the annual production had dropped to between 250 and 575 tons, and by 1874 only one furnace was operating (Strong, 1877, p. 744). From 1862 to 1876 , lead produced by the furnaces at Platteville totaled 6,275 tons (Strong, 1877, p. 744-745).

Zinc carbonate was first mined in the district in 1859 and zinc sultide as early as 1867. After 1873 more sulfide was mined than carbonate. The annual zinc production from the mining district first equaled that of lead in 1873, and for the next 20 years production of zinc and lead were roughly the same. Since 1893 the ratio of zinc to lead from ore mined in the district has generally ranged between $5: 1$ and $20: 1$.

Early zinc mines in the Platteville quadrangle included the Raisbeck and Gritty Six mines (southeastern corner of quadrangle), worked before and during the 1890's, and the Enterprise mine at Platteville, opened in 1899 . The only recent mining activity in the Platteville quadrangle has been at the Trego (secs. 10 and 11) and Acme (SE $1 / 4$ sec. 11), mines at Platteville, the Rasque mine (NW1/4 sec. 36), and the Big Jack mine (center of south line sec. 27), in T. 3 N., R. 1 W., near the center of the quadrangle, and the Depp (Fever River) mine (NE $1 / 4$ sec. 18 , T. 2 N., R. 1 E.) in the southeastern part of the quadrangle. In 1960 the New Jersey Zinc Co. started a large mine on ore bodies near Elmo.

The mines in the Platteville quadrangle have produced more than 2 million tons of ore since 1890, much of it high-grade zinc-lead ore. Production of zinc ore from individual mines in the quadrangle ranges 


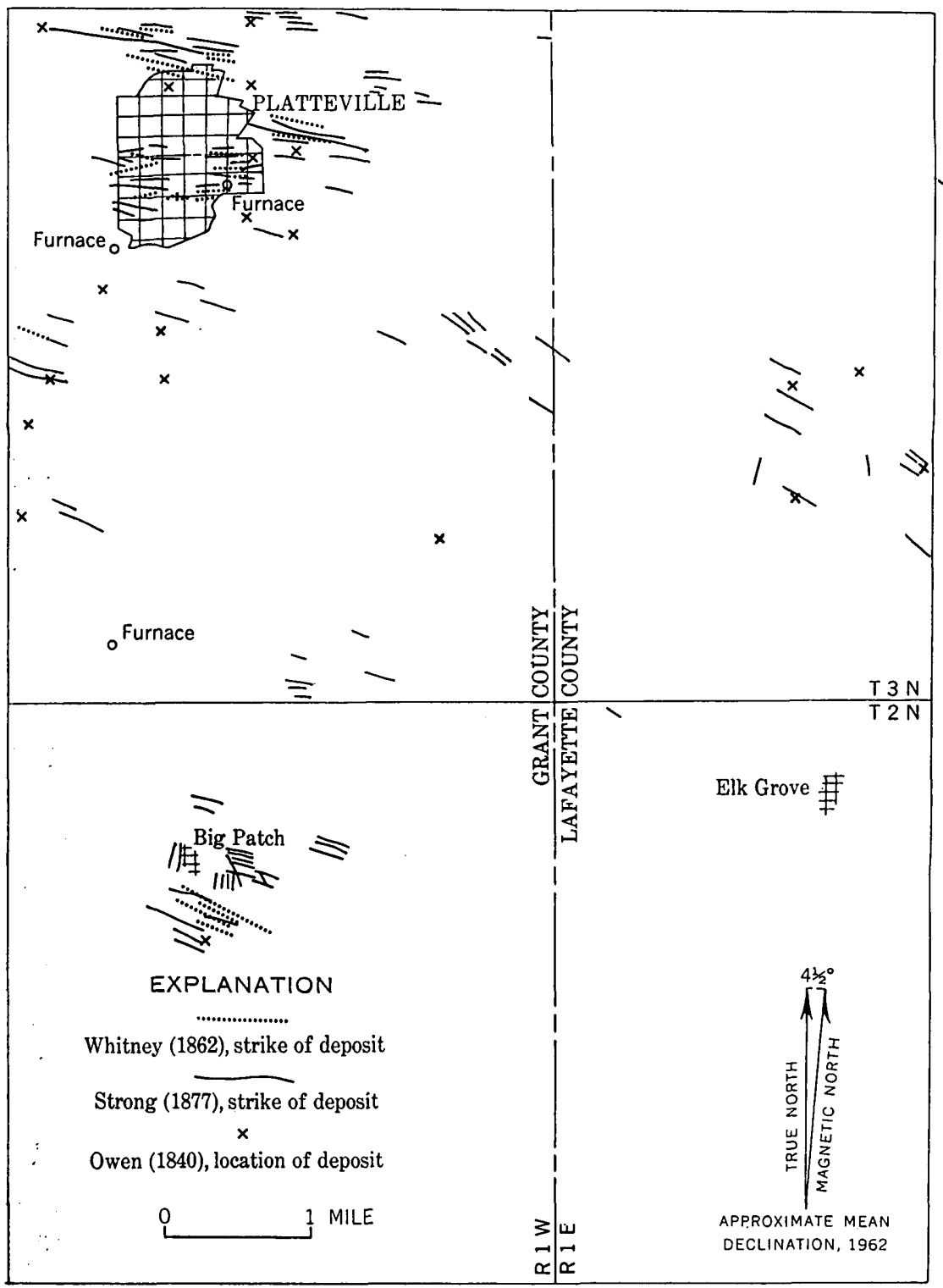

Figure 42.--Plat showing location of vertical-vein (crevice) lead deposits mapped in the Platteville quadrangle by previous surveys (Owen, 1840 ; Whitney, 1862; Strong, 1877)

from a few tons to an estimated 900,000 tons from the EnterpriseEmpire ore body. The Trego mine produced ore, some of which was hand sorted, that ranged from 3 to 7 percent zinc, and ore produced from the Depp (Fever River) mine ranged from 6 to 12 percent zinc. The grade of ore produced in the other mines ranged from 3 to 12 
percent, and probably the average grade of all ore produced was near: 6 percent. Small amounts of iron sulfide concentrate have been shipped from the zinc mines as low-grade iron ore, and much larger quantities have been used to manufacture sulfuric acid.

\section{VERTICAL VEINS (CREVICE DEPOSITS)}

Most of the lead ore in the quadrangle is associated with long vertical or steeply inclined fractures or joints known locally as crevices (Percival, 1855, p. 34-35). Generally those that strike a little south of east are more open, more likely to contain lead deposits, and more productive than those that strike in other directions. Where two or more crevices intersect, irregular vertical shoots or chimneys of lead ore may occur. In certain very permeable beds or groups of beds, solution along vertical or steeply inclined crevices has formed podlike cavities or zones of open pore spaces, locally called openings (Whitney, 1862 , p. 239). Above the water table, the cavities are partly filled with clay, dolomite sand, and blocks of dolomite.

The principal lead ore mineral, galena, occurs in the following ways: (1) as veins (sheets in miners' terminology) less than 1 inch thick along crevices, (2) as veins along bedding surfaces adjacent to crevices, (3) as encrustations on the walls of open crevices, (4) as cement in solution-brecciated zones along crevices, (5) as single crystals or small aggregates in the mixture of clay and dolomite sand that fills openings, and (6) as large masses embedded in clay and dolomite sand where leaching has caused the lead veins to collapse. Where crystallized, the galena occurs mainly as cubes but also as cubooctahedra. Locally galena is encrusted with the lead carbonate, cerussite, or the openings between cleavage plates of the galena may be partly filled with it.

Many crevices contain lead sulfide in openings above the static water table, zinc sulfide in openings below it, and a mixture that commonly includes zinc carbonate in openings at or near the water level, as in the Gritty Six-Raisbeck ore body in the southeastern corner of the quadrangle and the Board of Trade, Wicklow, and Jarrett mines along the southern border of the quadrangle. Some lead-bearing crevices or groups of crevices are in strata directly above inclined- and horizontal-vein (pitch-and-flat) zinc-lead ore bodies, as at the Trego mine north of Platteville and the Blockhouse mines in the west-central part of the quadrangle (pl. 19). In most places, however, the leadbearing crevices appear to cut across the trends of the zinc-lead ore bodies below, as in the Hodge, Enterprise, and Empire mines in the eastern part of Platteville.

Many vertical-vein deposits occur in groups of closely spaced, parallel or en-echelon crevices; others are several hundred feet from their 
nearest known neighbor. Groups of closely spaced vertical veins, or, more commonly, lines of discontinuous mine workings along such groupings, are locally called ranges. Closely spaced vein deposits that were mined in groups in the Platteville quadrangle include those at the Cabanis diggings at Big Patch (NE1/4 sec. 10, T. 2 N., R. 1 W.) and the Hells Point diggings at the east edge of Platteville (center N1/2 sec. 14, T. 3 N., R. 1 W.). Crevices are en echelon at the Flynn, Bevans, and Rountree ranges in the southeastern part of Platteville, SE $1 / 4$ sec. 15, T. 3 N., R. 1 W. (Percival, 1855, p. 70; Chamberlin and others, 1877, pl. 33).

In the Platteville quadrangle most of the lead ore was produced from the second and the upper flint openings (Percival, 1855, p. 85) in the Galena dolomite (fig. 40), but at the Buzzards Roost diggings above the Gritty Six-Raisbeck ore body in the southeast corner of the quadrangle lead ore was mined from the Guttenberg member of the Decorah formation. The upper flint opening is locally a zone containing three separate openings through a vertical interval of 25 to 30 feet, as at the village of Big Patch (Whitney, 1862, p. 277). The characteristic occurrence of lead ore at mines in the city of Platteville is in openings partly full of jumbled masses of dolomite with a matrix of dolomite sand and clay, as at the Davison and Co. range at the southeastern edge of the city (Chamberlin, 1882, p. 462).

Much of the lead ore mined at first was from concentrations of galena in red residual clay above or near crevices in bedrock. The village of Big Patch (sec. 10, T. 2 N., R. 1 W.) received its name from nearby diggings where a residual mass of galena 18 feet across and 3 feet thick was mined. This deposit was discovered in 1828 .

\section{INCLINED AND HORIZONTAL VEINS (PITCH-AND-FLAT DEPOSITS)}

In one type of deposit zinc and lead ore occurs principally in inclined veins locally called pitches and in bedding-plane veins known as flats (Percival, 1855, p. 53; Whitney, 1862, p. 230). Ore associated with pitches and flats occurs in shaly beds as disseminated crystals, in breccia zones as open-space filling referred to locally as brangle or honeycomb ore, and in vugs and other cavities as linings. Pitch-andflat deposits are confined to the lower part of the cherty unit of the Galena dolomite, the Decorah formation, and the Quimbys Mill member of the Platteville formation.

Pitch-and-flat ore bodies are linear in plan, and their alinement along the flanks of folds is related to groups of inclined fractures that occur where dips are steepest. An arcuate form of ore deposit results from the intersection of folds where fractures curve continuously around the noses of plunging flexures. 
The inclined fractures that control the zinc-lead ore bodies commonly dip away from synclinal areas. These fractures have displacements of a few inches to a few feet where they pass through the relatively competent beds of the Galena dolomite and the underlying dolomite of the Ion member of the Decorah formation. They generally terminate or flatten downward in the less competent shaly strata of the Guttenberg and Spechts Ferry members of the Decorah formation. Upward, they either terminate at a mineralized bedding plane, locally called the top flat, or continue as a single vertical or nearly vertical fracture. The fractures may be open or tight, and may contain clay gouge or geodelike fillings of sulfides and calcite. Slickensides attest to movement along these fractures.

Bedding-plane faults or horizontal fractures, detected by slickensides, are associated with the ore-bearing structures. Locally they have been enlarged by ore-bearing solutions. Where vein deposits are present, these flats have been mined.

The zinc ore mineral is sphalerite, which is about midway in the paragenetic sequence. It is typically rosin colored, although colors range from pale yellow to deep brown. The sphalerite is accompanied by a gangue of pyrite, marcasite, calcite, barite, and traces of chalcopyrite, and oxidation of these minerals has produced secondary carbonates, oxides, and sulfates. Sphalerite is altered to a porous, cellular form of smithsonite that is called drybone. Iron is redeposited as goethite and hematite, and manganese as wad, psilomelane, and pyrolusite which are especially abundant in the southeastern part of the quadrangle. Several stages of calcite occur as rhombohedral and scalenohedral crystals. Barite is mainly the massive variety. Chalcopyrite is associated with iron sulfides and calcite, and has been altered to copper oxides, sulfides, and carbonates.

All the zinc mines in the Platteville quadrangle are in pitch-andflat ore bodies. Those in the southeastern part, north of the Meekers Grove anticline, are characterized more by solution-breccia ore than by the typical inclined and horizontal veins. Zinc mines near the center of the south boundary line are at the position of the upper flint opening (fig. 40). These deposits are in vertical crevices that bifurcate downward into two pitches (George, 1915) and therefore are a combination of vertical-crevice and pitch-and-flat types.

\section{ZINC MINES}

Most of the zinc ore bodies in the Platteville quadrangle have been described by Heyl and others (1959). One mine in each of the two main varieties of pitch-and-flat bodies-typical and solution-breccia-. is described in the following paragraphs. The Rasque mine, which 
was the only mine in operation when the Platteville quadrangle was being mapped, is also described. Other zinc mines in the quadrangle are listed in table 1.

The Trego mine is in the $\mathrm{E}_{1} / 2 \mathrm{SE}^{1} / 4 \mathrm{NE}^{1 / 4}$ sec. 10 and the $\mathrm{S} 1 / 2 \mathrm{NW} 1 / 4$ sec. 11, T. 3 N., R. 1 W. (pl. 19). This typical pitch-and-flat ore body is arcuate in plan, has a distinct nose at the west end, and lies within a syncline that trends westward (Heyl and others, 1959, p. 115, 117, and pl. 11). The ore body is controlled by a horseshoe-shaped zone of inclined fractures that strike generally eastward and dip outward. At the eastern end of the north limb the fault zone swings north and then west, around the east nose of an anticline.

The ore occurs as well-developed inclined and horizontal veins in fractures in the Guttenberg and Ion members of the Decorah formation and the lower cherty unit of the Galena dolomite. It contains zinc and iron sulfides, a little barite and chalcopyrite, and locally calcite. Stope heights in the mine range from 6 to 45 feet, but in general are about 15 to 20 feet.

Two parts of the Trego ore body were discovered by drilling about 1905 and were mined separately for several years as the Trego mine and the Great Northern mine. The area near both mines was drilled in 1918 by the Wisconsin Zinc Co., and considerable additional ore was discovered. The Trego mine, including the old Great Northern on the south limb of the ore body, was operated successfully from March 1943 to September 1945 by the Piquette Mining Co., but was closed because the ore was lean. Hand-cobbed ore mined during this period contained between 3 and 7 percent zinc and considerable iron. When they were abandoned, headings at the east end of the north and south limbs showed lean ore of about 2 to 3 percent zinc. Some ore may also remain at the west nose and beneath the present floor of the north limb near the west nose, but other parts of the ore body have been worked out.

An example of the solution-breccia deposits is at the Depp (Fever River) mine (Heyl and others, 1959, fig. 90 ) in the $\mathrm{S} 1 / 2 \mathrm{NE} 1 / 4$ sec. 18, T. 2 N., R. 1 E. This small but rich ore body has a sharp arcuate nose to the south around a small anticline. The ore body, about 7 feet thick, has been mined for a length of 750 feet. It is localized in the lower part of the Ion member, although some ore minerals occur in the underlying Guttenberg member. The ore was found in flat veins 20 feet wide. Locally at the southeastern part of the south nose an arcuate inclined vein (pitch) dips into the small central anticline. A fracture that trends N. $40^{\circ} \mathrm{E}$. across the ore body 80 feet northwest of the shaft is reported to be a small fault along which the beds on the northwest side moved upward (Francis Piquette, oral commu- 
nication, 1944). The sphalerite occurred mostly within veins of pyrite and marcasite, and only locally was the ore rich in sphalerite.

The ore body was discovered by drilling about 1907, and a shaft was sunk to a depth of 100 feet in late 1907 or early 1908. The mine operated about 1 year but was then closed, and was not developed until late in 1941. From January to August 1942 the mine produced ore averaging 12 percent zinc and 0.5 percent lead, and from June to October 1943 the ore averaged 12 percent zinc and 0.2 percent lead. A small amount of ore was intersected by old drill holes within half a mile west of the mine (Heyl and others, 1959, pl.3).

The Rasque ore body is the center of the quadrangle (NW1/4 sec. 36, T. 3 N., R. 1 W.), near the esatward projection of the long line of almost continuous zinc-lead ore bodies of the Blockhouse Range. The ore was discovered by drilling about 1949 and was mined at two levels in 1952 and 1953. The lower or 155-foot level was developed in a typical pitch-and-flat deposit in the lower part of the Ion, the Guttenberg, and Spechts Ferry members of the Decorah formation and in the Quimbys Mill member of the Platteville formation. Typical sphalerite vein ore is related to an inclined fracture, that strikes N. $35^{\circ} \mathrm{W}$. and dips southwestward, along which short drifts were driven. The upper or 105-foot level, in Galena dolomite at the approximate level of the water table, contains mined veins of sphalerite, smithsonite, and galena for a short distance northeastward from the shaft along vertical fractures that strike N. $15^{\circ} \mathrm{E}$. Also at the 105foot level, galena was mined by a 50-foot raise from the 155-foot level along a N. $30^{\circ} \mathrm{W}$. vertical joint about 50 feet east of the shaft. Between these two levels, in the basal part of the Galena dolomite and the upper part of the Ion member, was a zone of solution breccia and disseminated zinc and iron sulfides in exceedingly fine crystals and grains.

Most of the drilled-out ore was not mined. The rock was soft for 35 feet above the 105-foot level, and difficulty in maintaining a solid roof was reportedly one factor that caused the mine to be closed. 
Location of mines in the Platteville quadrangle is given in table 1.

TABLE 1.-Location of zinc mines in the Platteville quadrangle

[See Heyl and others $(1959$, p. 232-251) for detailed descriptions and maps of all the mines]

\begin{tabular}{l|l|l}
\hline Mine & Sec. location & Other reference \\
\hline
\end{tabular}

Platteville area, T. 3 N., R. 1 W.

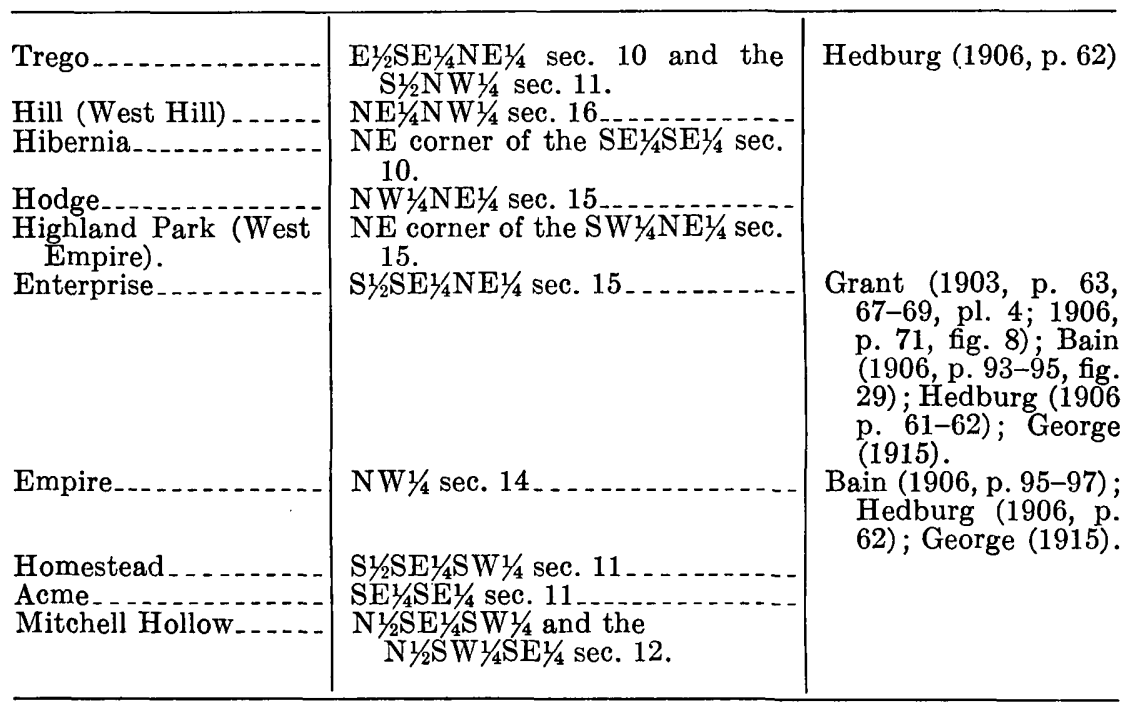

Blockhouse Range, T. 3 N., R. 1 W.

\begin{tabular}{|c|c|}
\hline 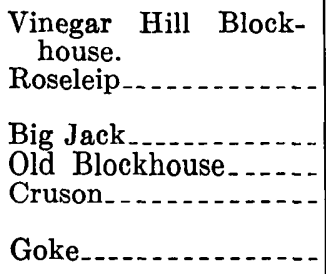 & $\begin{array}{l}\text { S1/2 sec. } 28 \text { and } N 1 / 2 \text { sec. } 33 \\
\text { SW1/4SW1/4 sec. } 27 \text { and SE1/4SE1/4 } \\
\text { sec. } 28 \text {. } \\
\text { SE1/4SW1/4 sec. } 27 \\
\text { S1/2SE1/4 sec. } 27 \\
\text { SW1/4SW1/4 sec. } 26 \text { and SE1/4SE1/4 } \\
\text { sec. } 27.4 \\
\text { SW1/4SW1/4 sec. } 26\end{array}$ \\
\hline
\end{tabular}

Other mines in T. 3 N., R. 1 W.

\begin{tabular}{|c|c|}
\hline $\begin{array}{l}\text { Weigle } \ldots \ldots \\
\text { Rasque } \ldots \ldots \\
\text { Lyght....... }\end{array}$ & $\begin{array}{l}\text { NE1/4NW1/4 sec. } 36 \\
\text { SE1/4NE1/4NW1/4 sec. } 36 \ldots \ldots \\
\text { SE1/4SE1/4 sec. } 34 \ldots \ldots\end{array}$ \\
\hline
\end{tabular}


TABLE 1.-Location of zinc mines in the Platteville quadrangle-Continued

[See Heyl and others (1959, p. 232-251) for detailed descriptions and maps of all the mines]

\begin{tabular}{|c|c|c|}
\hline Mine & Sec. location & Other reference \\
\hline \multicolumn{3}{|c|}{ T. 2 N., R. 1 W. } \\
\hline $\begin{array}{l}\text { Beloit-Elmo } \\
\text { Black Hawk. } \\
\text { Little Dick } \\
\text { Board of Trade } \\
\text { North Wicklow } \\
\text { (Jarrett). }\end{array}$ & $\begin{array}{l}\text { SE1/4SW1/4 sec. } 2 \\
\text { NE1/4NE1/4 sec. } 10 \\
\text { W1/2NE1/4SE1/4 sec. } 23 \\
\text { SE1/4SE1/4 sec. } 23 \\
\text { S1/2SE1/4SW1/4 sec. } 24\end{array}$ & George (1915). \\
\hline
\end{tabular}

T. 2 N., R. 1 E.

\begin{tabular}{|c|c|c|}
\hline $\begin{array}{l}\text { Peaceful Valley } \\
\text { Best } \\
\text { Masbruch } \\
\text { Depp (Fever River) } \\
\text { Big Ten } \\
\text { Koll } \\
\text { Lawrence. } \\
\text { Uniset opencut } \\
\text { Raisbeck-Gritty Six. } \\
\text { Cuba City } \\
\text { Henrietta. } \\
\text { Midway }\end{array}$ & 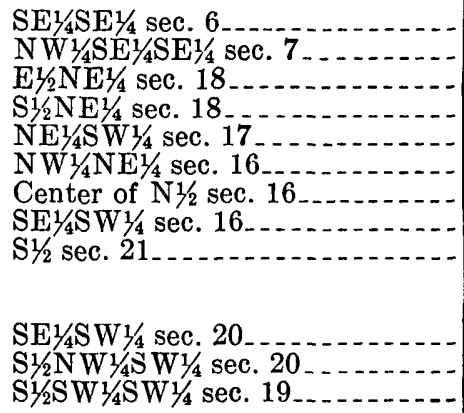 & $\begin{array}{c}\text { Grant (1903, p. 63, } \\
71-72) \text {; Bain (1906, } \\
\text { p. 90-91, fig. 25). }\end{array}$ \\
\hline
\end{tabular}

\section{IRON SULFIDE DEPOSITS}

Iron sulfide minerals are present in all pitch-and-flat deposits in the Platteville quadrangle; in fact, many of the zinc ore bodies contain more iron sulfide than zinc sulfide. Small amounts of iron sulfide concentrate have been shipped as low-grade iron ore. Some of the mines, such as the Uniset (SW1/4 sec. 16, T. 2 N., R. 1 E.), were operated mainly for their iron sulfide rather than zinc or lead. In recent years an iron sulfide concentrate was produced and roasted to obtain sulfur for the preparation of sulfuric acid. The sulfuric acid plant was dismantled in 1949, and currently there is no local market for the iron sulfide. Inasmuch as the zinc ore bodies contain from 6 to 40 percent $\mathrm{FeS}_{2}$, this potential source of sulfur should not be overlooked.

Mines in the Platteville quadrangle that contained a high percent of iron sulfide include, in addition to the Uniset, the Cuba City, Henrietta, Big Ten, Depp or Fever River, and the Peaceful Valley, all in T. 2 N., R. 1 E. (table 1); and the Lyght, Hibernia, and the Great Northern part of the Trego in T. 3 N., R. 1 W. (table 1) near Platteville. 
Pyrite, an early mineral in the paragenetic sequence, coats the walls of fractures. Both pyrite and marcasite occur along the outer walls of the veins, although some of the marcasite is later and occurs near the center of the veins. Marcasite is present as dull-grayishgreen sooty reniform masses that are readily oxidized, and as bright brassy bladed cockscomb crystals. Crystals of pyrite are commonly scattered in the wallrock. Cubic pyrite is most common, but octahedra also occur. Iron sulfide generally borders the zinc deposits and thus acts as a halo.

\section{ROCK ALTERATION RELATED TO ORE DEPOSITS}

Leaching, dolomitization, and less commonly silicification have locally altered the carbonate rocks. This dolomitization is not the same as the regional dolomitization that has affected the Platteville, Decorah, and Galena formations of the upper Mississippi Valley area (Agnew and others, 1956, fig. 34). Partial or complete removal of carbonates along fractures or other openings probably by mineralizing solutions, and subsequent concentration of argillaceous material by compaction and collapse have resulted in thinning of the formations.

Mineral-bearing solutions have locally thinned the McGregor limestone member of the Platteville formation to a mass of grayish dolomitic clay. Similarly, the limestone of the Quimbys Mill member of the Platteville formation has been leached to a dark-brown banded shale and dolomite, and reduced in places in the southeastern part of the quadrangle from a normal thickness of 9 feet to less than 3 feet. The calcareous parts of the Spechts Ferry member of the Decorah formation have been leached, leaving a residue of plastic clay. The Guttenberg member of the Decorah formation was thinned in a manner similar to the Quimbys Mill member, and its normal thickness of 16 feet was reduced to $4 \frac{1}{2}$ feet at one outcrop 500 feet west of the quadrangle border (center of $\mathrm{W} 1 / 2$ sec. $16, T .3 \mathrm{~N} ., \mathrm{R} .1 \mathrm{~W}$.) and to less than that in places in the southeastern part of the quadrangle, as indicated by prospect drill holes. Leaching of the Ion member of the Decorah formation and the lower part of the Galena dolomite has not been detected in the Platteville quadrangle, but elsewhere in the mining district these zones have been reduced to as little as half their normal thickness; the shaly strata of the Ion have thus acquired a concentration of argillaceous residuum, and the Galena strata have thus become a porous, cellular mass of coarse-grained dolomite sand.

In the Platteville quadrangle, dolomitization accompanying the mineralizing solutions affected the Quimbys Mill and Guttenberg strata particularly, and produced a sugary texture. Dolomitization of 
the Ion member in the Trego mine north of Platteville (secs. 10 and 11, T. 3 N., R. 1 W.), gave the already dolomitic limestone a generally bleached appearance and added a few thin veins of milky dolomite. This dolomitization was superimposed on the regional dolomitization of the eastern part of the mining district (Agnew and others, 1956, fig. 34), and the regional dolomitization was apparently related to the Wisconsin arch (fig. 38), an important structural feature active during and after the Ordovician.

Silicification related to mineralizing solutions noticeably affected only the Guttenberg member. Replacement by silica has preserved most of the original texture of the limestone; where most advanced it has produced some brown chert nodules unlike the chert nodules in unaltered Guttenberg (p. 255). Another type of silicification, along the Meekers Grove anticline just east and southeast of the Platteville quadrangle, changed the Quimbys Mill and McGregor strata to slightly porous, spongelike yellowish-brown rock. The distribution of this type of silicification suggests that it is related to the Meekers Grove anticline rather than to ore trends.

\section{ORIGIN OF THE ORE DEPOSITS}

Genesis of the zinc-lead deposits of the mining district has been a controversial topic since Whitney (1862, p. 380-406) suggested that zinc and lead minerals were deposited from circulating meteoric waters by concentration and redeposition of sulfides which were originally deposited during the precipitation of the carbonate strata. This opposed earlier views of Owen (1847, p. 160-173) and Percival (1855, p. $100 ; 1856$, p. 63 ), who thought that the ores originated from hydrothermal sources. Whitney's ideas were later refined by Chamberlin (1882, p. 522-553) and restated by Bain (1906, p. 124-142). Chamberlin postulated that a source for the minerals could have been in the Precambrian rocks to the north, and that preliminary concentration took place in the sea by eddies and currents. Van Hise (1901) believed that the ore originated by lateral secretion followed by secondary enrichment by surface waters. Investigations by Emmons (1929), Newhouse (1933), Graton and Harcourt (1935), Garrels (1941), and Heyl and others (1959), indicate a probable low-temperature hydrothermal origin for these deposits. Nevertheless, some aspects of the vein formation such as leaching, oxidation, and redeposition are characteristic of deposits formed through the action of meteoric water. 
Exploration for vertical-vein (crevice) lead deposits can be restricted to certain more permeable zones in the Galena dolomite. Most of the mineralized outcrops were detected by 1830 (Agnew, 1955, p. 786), but the early lead mining was restricted to shallow depths because of water; therefore exploration of unprospected openings beneath the water table should be considered. Sinkholes and other evidence of solution cavities, as in secs. 16 and 17, T. 2 N., R. 1 E., in the southeastern part of the quadrangle, indicate open fractures or zones of shearing that may be related to underlying mineralized structures.

Exploration for inclined and horizontal veins (pitch-and-flat deposits) of zinc ore can be restricted to the lower part of the Galena dolomite, the Decorah formation, and the upper part of the Platteville formation. Beds of the Quimbys Mill member of the Platteville formation are known to contain ore in the southeastern, central, and northwestern parts of the Platteville quadrangle. Most of the early prospecting did not penetrate the Quimbys Mill, so it is still unexplored throughout much of the quadrangle. This lower zone remains a potential source of zinc-lead ore, particularly beneath such large mines as the Gritty Six and Raisbeck in the southeast, the mines of the Blockhouse Range in the west-central part of the quadrangle, and the mines at the east edge of Platteville. By using the stratigraphic thicknesses (fig. 40), the structure contours, and the topographic contours (pl. 19), the depth to the Quimbys Mill member can be closely estimated.

Lead and zinc minerals have been found in the Prairie du Chien group in other parts of the mining district during the past few years (Heyl and others, 1951; Agnew and others, 1953); however, as the lithology of the Prairie du Chien group is too variable, and as known deposits in it are small and of low grade, exploration at the depths necessary to reach possible deposits in the Platteville quadrangle does not seem to be profitable at present.

Areas of steeply dipping and sheared rocks on the flanks of folds are more favorable for exploration than undeformed areas, but they are not all ore bearing. Alteration of the favorable host rocks, as along the Little Platte River in the SW1/4 sec. 9, T. 3 N., R. 1 W., may indicate ore mineralization.

The detailed appraisals of an area may be aided by constructing isopach maps that show thinning of the Guttenberg and Quimbys Mill members. Areas of such thinning, which is related to ore-depositing solutions, occur in sec. 16 west of Platteville, in sec. 18, T. 3 N., R. 1 E., east of Platteville, and in the southeastern part of the quadrangle. 
Churn drilling has been the common method used in exploring for the zinc-lead ore bodies. Drilling is necessary because large parts of the mining district are covered by a mantle of surficial material and are in undissected areas where erosion has not disclosed potentially ore-bearing strata. Rotary core drilling provides a more acceptable sample than the churn-drill cuttings, but in fractured rock the return sludge is commonly lost, or expensive cementing jobs are required. Soil augers, whether power driven or hand operated, could be used to sample surficial material adequately to detect the Maquoketa shaleGalena dolomite contact for mapping of geologic structure (Allingham and others, 1955).

In areas of sparse geologic information the presence of folds can be determined in sufficient detail to guide exploration by an initial grid of holes drilled on 1,320-foot centers, which is the spacing commonly used in the district. Mineralized ground or areas considered favorable because of structural and stratigraphic criteria can then be prospected by cross sections of holes until the geometry of the body is known (Agnew, 1955, p. 787). The spacing of drill holes is governed by the width of the expected ore body. Bodies such as those at Platteville, and the Gritty Six-Raisbeck ore body in the southeastern part of the quadrangle, can be prospected by holes drilled generally with 100 foot spacing, whereas narrow bodies such as the Little Dick and the Board of Trade-North Wicklow-Jarrett, along the southern border of the quadrangle, would require spacing no greater than 25 feet. The vertical-crevice lead deposits are very difficult to find with the churn drill as they are narrow, averaging 5 to 8 feet in width (Whitney, 1862, p. 321).

Successful exploration depends partly on an accurate survey of the drill holes and careful examination of the cuttings. The size and grade of an ore deposit can be determined from drilling information (Boericke and Garnett, 1919, p. 1234). However, a well-planned exploration program may be seriously hampered and the data invalidated by improper sampling, inaccurate records of depths, excessive washing of the drill cuttings, and down-hole contamination by caving of soft altered mineral-bearing ground.

Geochemical prospecting of residual clay with the use of augers has been successful in locating mineralized areas where fractures reach the surface of the bedrock (Agnew, 1955, p. 792); this method of testing has been used with some success particularly in the southeastern part of the quadrangle.

The successful development and operation of mines in the Platteville quadrangle is partly dependent on the quantity of water that must be pumped from the mines in order to drain them. Most mines 
in the Platteville quadrangle, such as in the Blockhouse Range and those at Platteville, pumped only a few hundred gallons of water per minute. Other such as the Beloit-Elmo mine near Big Patch (pl. 19) were scarcely workable because of the very large flow of water, and the Depp or Fever River mine (NE1/4 sec. 18, T. 2 N., R. 1 E.) is reported to have pumped 3,000 gallons per minute.

\section{NONMETALLIC DEPOSITS}

Barite.-This is an exceedingly common constituent in the pitchand-flat ore body of the Gritty Six and Raisbeck mines in the southeast corner of the quadrangle. It occurs as a flat bedded vein extending out from a southward-dipping fracture along the south wall of the Raisbeck mine, and it reaches a width of as much as 40 feet and a height of $5 \frac{1}{2}$ feet. The vein also contains disseminated crystals of galena and is reportedly in the Ion member of the Decorah formation. This spar range is just south of the ore body and was also found at the Gritty Six mine to the west. Shipments of barite that were reported to assay 90 to 93 percent $\mathrm{BaSO}_{4}$ were made from 1918 to 1920 and 1923 to 1930 .

A similar concentration of barite was mined from the diggings a few hundred feet south of the Raisbeck mine. In these diggings barite was associated with galena and some zinc carbonate in northeastwardtrending fractures. The ore zone was apparently in the lower chert zone and the lower Receptaculites zone of the cherty unit of the Galena dolomite.

Building stone.-In the Platteville quadrangle dense limestone (glass rock) of the Quimbys Mill member has been used locally for building, particularly in the city of Platteville. This rock was quarried along the Little Platte River just west of town. It makes a fine building stone of pleasing color when weathered, but the quarry faces near Platteville are only about 4 to 5 feet high.

The thick-bedded Galena dolomite in the lower part of the noncherty unit could possibly be used for building stone, as has been done near Dubuque, Iowa (Grant and Burchard, 1907, p. 13).

Clays.-A brickyard was operated in Platteville (SE corner sec. 10, T. 3 N., R. 1 W.) beginning in 1874 (Strong, 1877, p. 665). Residual clay was dug from nearby valley walls, and its grayish-yellow color became red on burning in the kiln. This yard made an estimated 8,000 bricks per day.

Clays near the base of the Maquoketa could probably be used for the manufacture of clayware, and clays from the Spechts Ferry member along the Little Platte River have been used to make terra-cotta ware (Grant and Burchard, 1907, p. 13). 
Cement materials.-The argillaceous limestone of the McGregor, Guttenberg, and Ion members might be fairly suitable for the manufacture of portland cement.

Road aggregate.-Dolomite, limestone, and chert are all quarried for use as road metal in the Platteville quadrangle, and adequate supplies are available. Several of the larger quarries are shown on plate 19 near Platteville and Big Patch. Chert in dolomite is a deterrent for good concrete mix, as it causes pop-outs; yet the cherty Galena dolomite continues to be used in concrete highway construction. The jig tailings from the zinc mines have long been widely used for secondary-road material, and have a ready market when they are available as a mine byproduct.

Agricultural limestone.-Most of the quarries in the Galena dolomite produce agricultural lime. Indeed, the magnesian content of the dolomitic rock makes it a premium material because of its high equivalent- $\mathrm{CaO}$ assay.

Soils.-As might be expected, the soils of the Platteville quadrangle reflect the character of the surface material (loess) and topographic position. They seem to be not at all influenced by the contrast in bedrock between the Galena dolomite and the Maquoketa shale in the southwestern part of the quadrangle, although the soil near the position of the contact is poorly drained in sec. $21, T .2$ N., R. $1 \mathrm{~W}$. The soils of the farms on the broad divide that extends northward in the central part of the quadrangle are particularly thick and rich, and in general, the farms on them have been very successful. The economic value of the soils is noted by Hole and others (1952).

\section{REFERENCES CITED}

Agnew, A. F., 1953, Data on recent drilling in the zinc-lead area of WisconsinDescriptive logs of exploratory holes drilled during 1952 by the U.S. Geological Survey in Ipswich Northwest quadrangle, Wisconsin: U.S. Geol. Survey open-file report.

- 1955, Application of geology to the discovery of zinc-lead ore in the Wisconsin-Illinois-Iowa district: Mining Eng., v. 7, no. 8, p. 781-795; 1956, Am. Inst. Mining Metall. Engineers Trans. 1955, v. 202.

Agnew, A. F., and Heyl, A. V., Jr., 1946, Quimbys Mill, new member of Platteville formation, upper Mississippi Valley: Am. Assoc. Petroleum Geologists Bull., v. 30, p. 1585-1587.

Agnew, A. F., Flint, A. E., and Allingham, J. W. 1953, Exploratory drilling program of the U.S. Geological Survey for lead-zinc in Iowa and Wisconsin, 1950-51: U.S. Geol. Survey Circ. 231.

Agnew, A. F., Flint, A. E., and Crumpton, R. P., 1954, Geology and zinc-leadbarite deposits in an area in Lafayette County east of Cuba City, Wis.: U.S. Geol. Survey Mineral Inv. Field Studies Map MF-15.

Agnew, A. F., Heyl, A. V., Jr., Behre, C. H., Jr., and Lyons, E. J., 1956, Stratigraphy of Middle Ordovician rocks in the zinc-lead district of Wisconsin, Illinois, and Iowa : U.S. Geol. Survey Prof. Paper 274-K, p. 251-311. 
Allingham, J. W., Flint, A. E., and Agnew, A. F., 1955, Zinc and lead deposits of the Sinsinawa River area, Grant County, Wis.: U.S. Geol. Surrey Mineral Inv. Field Studies Map MF-40.

Anderson, K. E., 1950, Basement complex biotite granite at Dubuque, Iowa : Iowa Acad. Sci. Proc., v. 57, p. 241-244.

Bain, H. F., 1906, Zinc and lead deposits of the upper Mississippi Valley : U.S. Geol. Survey Bull. 294, 155 p.

Boericke, W. F., and Garnett, T. H., 1919, The Wisconsin zinc district: Am. Inst. Mining Metall. Engineers Trans., v. 152, p. 1213-1235.

Chamberlin, T. C., 1882, The ore deposits of southwestern Wisconsin; Geology of Wisconsin: Wisconsin Geol. Survey, v. 4, p. 365-571.

Chamberlin, T. C., and others, 1877, Atlas of the geological survey of Wisconsin : Milwaukee, Wis., Wisconsin Geol. Survey.

Chamberlin, T. C., and Salisbury, R. D., 1885, Preliminary paper on the Driftless Area of the upper Mississippi Valley: U.S. Geol. Survey 6th Ann. Rept., p. 199-322.

Cox, G. H., 1911, The origin of the lead and zinc ores in the Upper Mississippi Valley district: Econ. Geology, v. 6, no. 6, p. 427-448, 582-603.

Daniels, Edward, 1854, First annual report on the geological survey of the State of Wisconsin, Madison, Wis., Wisconsin Geol. Survey, $84 \mathrm{p}$.

Emmons, W. H., 1929, The origin of the sulphide ores of the Mississippi Valley : Econ. Geology, v. 24, no. 3, p. 221-271.

Flint, A. E., 1956, Stratigraphic relations of the Shakopee dolomite and the St. Peter standstone in southwestern Wisconsin: Jour. Geology, v. 64, no. 4, p. $396-421$.

Garrels, R. M., 1941, The Mississippi Valley type lead-zinc deposits and the problem of mineral zoning: Econ. Geology, v. 36, no. 7, p. 729-744.

George, H. C., 1915, The Wisconsin zinc district: Eng. and Mining J'our., v. 100, p. $295-300,341-344,385-388$.

Grant, U.S., 1903, Preliminary report on the lead and zinc deposits of southwestern Wisconsin: Wisconsin Geol. and Natl. History Survey Bull. 9, 103 p.

- 1906, Report on the lead and zinc deposits of Wisconsin: Wisconsin Geol. and Natl. History Survey Bull. 14, 100 p.

Grant, U.S., and Burchard, E. F., 1907, Description of the Lancaster and Mineral Point quadrangles, Wis. : U.S. Geol. Survey Geol. Atlas, Folio 145, 14 p.

Graton, L. C., and Harcourt, G. A., 1935, Spectrographic evidence on the origin of the ores of Mississippi Valley type: Econ. Geology, v. 30, no. 7, p. 800-824.

Hedburg, Eric, 1906, The Wisconsin zinc field: Mining World, v. 24, p. 60-63.

Heyl, A. V., Jr., Agnew, A. F., and Behre, C. H., Jr., 1945, Zinc deposits of the Meekers Grove (Jenkinsville) area of the Wisconsin zinc-lead district: U.S. Geol. Survey Strategic Minerals Inv. Prelim. Rept. 3-161, 6 p.

Heyl, A. V., Jr., Agnew, A. F., Lyons, E. J., and Behre, C. H., Jr., 1959, Geology of the Upper Mississippi Valley zinc-lead district: U.S. Geol. Survey Prof. Paper 309, $310 \mathrm{p}$.

Heyl, A. V., Jr., Lyons, E. J., and Agnew, A. F., 1951, Exploratory drilling in the Prairie du Chien group of the Wisconsin zinc-lead district by the U.S. Geological Survey in 1949-50 : U.S. Geol. Survey Circ. 131, 35 p.

Hole, F. D., Robinson, G. H., Dehnert, George, and Dahms, F. C., 1952, Soils maps of Platteville and Smelser township, Grant County, Wis.: Soil Survey Div., Wisconsin Geol. and Natl. Hist. Survey, also available from Agricultural Exp. Sta., Univ. Wisconsin. 
Irving, R. D., 1877, Geology of central Wisconsin: Geology of Wisconsin, v. 2, p. $407-642$.

Ladd, H. S., 1929, The stratigraphy and paleontology of the Maquoketa shale of Iowa : Iowa Geol. Survey, vol. 34, p. 305-448.

Martin, Lawrence, 1916, The physical geography of Wisconsin: Wisconsin Geol. and Natl. History Survey Bull. 36, $549 \mathrm{p}$.

Newhouse, W. H., 1933, The temperature of formation of the Mississippi Valley lead-zinc deposits : Econ. Geology, v. 28, no. 8, p. 744-750.

Owen, D. D., 1840, Report of a geological exploration of part of Iowa, Wisconsin, and Illinois in 1839 : U.S. 26th Cong., 1st. sess., H. Ex. Doc. 239, 161 p.

1847 , preliminary report of progress of the geological survey of Wisconsin and Iowa : U.S. General Land Office Rept., p. 160-173.

Percival, J. G., 1855, Annual report on the geological survey of the State of Wisconsin: Madison, Wis., Wisconsin Geol. Survey, $101 \mathrm{p}$.

1856, Second Annual report of the geological survey of the State of Wisconsin : Madison, Wis., Wisconsin Geol. Survey, 101 p.

Shaw, E. W., and Trowbridge, A. C., 1916, Description of the Galena and Elizabeth quadrangles, Illinois-Iowa: U.S. Geol. Survey Geol. Atlas, Folio 200, $13 \mathrm{p}$.

Steidtmann, Edward, 1909, in Hotchkiss, W. O., and Steidtmann, Edward, Geological maps of the lead and zinc district: Wisconsin Geol. and Natl. History Survey, Supplement to Bull. 14.

Strong, Moses, 1877, Geology and topography of the lead region: Geology of Wisconsin, v. 2, p. 643-752.

Thwaites, F. T., 1931, Buried pre-Cambrian of Wisconsin: Geol. Soc. America Bull., v. 42, no. 3, p. 719-750.

Trowbridge, A. C., 1921, The erosional history of the Driftless Area : Iowa Univ. Studies Natl. History, 1st ser., no. 40, v. 9, no. 3, 127 p.

1954, Mississippi River and Gulf Coast terraces and sediments as related to Pleistocene history-a problem: Geol. Soc. America Bull., v. 65, p. 793-812.

Van Hise, C. R., 1901, Some principles controlling the deposition of the ores: Am. Inst. Mining Metall. Eng. Trans., v. 30, p. 27-177.

Whitney, J. D., 1862, in Hall, James, and Whitney, J. D., Report of the geological survey of the State of Wisconsin: Albany, N.Y., Wisconsin Geol. Survey, p. 73-420.

Willman, H. B., and Templeton, J. S., Jr., 1952, Cambrian and Lower Ordovician exposures in northern Illinois: Ill. Acad. Sci. Trans. 1951, v. 44, p. 109-125; reprinted in Ill. Geol. Survey Circ. 179, p. 109-125, 1952. 